MAGDALENA GRELA-CHEN ${ }^{1}$

\title{
ANTITHESIS VERSUS INSPIRATION: CHINESE CLOTHING IN THE EYES OF WESTERN THEORISTS AND FASHION DESIGNERS
}

\begin{abstract}
Dress is a part of Chinese cultural heritage that has fascinated Western audiences for centuries. On the National List of Intangible Cultural Heritage of China, there are items related to textiles, embroideries and certain examples of Chinese clothing. This article analyzes issues connected with the different uses of Chinese dress in the West. To fashion theorists such as Quentin Bell, Elizabeth Wilson, Edward Sapir, and Thorstein Veblen, Chinese dress was the opposite of modern Western clothing and did not deserve to be called fashion. However, researchers such as Linda Welters, Abby Lillethun, and Jennifer Craik have opposed viewing fashion theory through a Eurocentric prism in their desire to rewrite fashion history. Fashion designers drew ideas from China, treating it as a source of inspiration to create their own original designs. For some of them, such as Yves Saint Laurent, it was a China of their imagination. In certain cases, they made use of porcelain designs or dragon motifs in their own collections, for instance, in designs by Roberto Cavalli and Tom Ford. The incorporation of Chinese garments into Western collections has also become visible.
\end{abstract}

Keywords: fashion, dress, intangible heritage, China, West

\section{INTRODUCTION}

For centuries, China has been the subject of keen Western interest being perceived as a faraway land full of treasures, such as delicate silk and fine porcelain, and the center of a rich culture so distant from that of Europe.

${ }^{1}$ PhD Candidate; Jagiellonian University in Kraków; ORCID: 0000-0002-2646-4191; magdalena.grela@student.uj.edu.pl. 
Chinese products were transported via the Silk Road to fulfill the desires of people around the world. Knowledge of China was based on these products, as well as upon books and stories relayed by travelers, all of which opened a door to admiration, fantasy, or dreams far from reality. However, this also gave rise to misunderstandings, hidden fears, and feelings of the superiority of one culture over another. This paper focuses on one aspect of Chinese cultural heritage - clothing. Dress is treated as an instrument in order to demonstrate the diverse use of Chinese culture in the West.

The aim of this study is to show how differently a certain style of dress can be perceived in the fashion industry, as well as on the theoretical level. The examples analyzed here were chosen in order to show common practices and dominant tendencies. Fashion designers have treated Chinese dress as a source of limitless inspiration. There is also the question of when inspiration transforms into "copycatting". Western theorists of fashion tend to use the example of Chinese dress while describing their own concept of fashion. Thus, Chinese dress is placed in opposition to Western fashion and is not considered equal to it. The question arises as to whether fashion can be a unique phenomenon; thus, can one society insist on being its only inventors, protecting their primacy in this field?

\section{CHINESE DRESS AS NATIONAL CULTURAL HERITAGE}

The Chinese Ministry of Culture has prepared a National List of Intangible Cultural Heritage of China. Among the listed items, those related to traditional arts and handicrafts can be found, some of which are associated with dressmaking techniques. In the first batch of items, dated May 20, 2006, traditional embroideries and stitches were recognized. This included guxiu (顾绣), suxiu (苏绣), xiangxiu (湘绣), yuexiu (粤绣), shuxiu (蜀绣), miaoxiu (苗绣), mawei xiu (馬尾繡), and panxiu (盘绣) embroideries, as well as the tiaohua (挑花) cross-stitch. Moreover, this batch comprised printing and dyeing techniques for Nantong blue calico (nantong lan yinhua bu, 南通藍印花布) and Miao batik (miaozu laran jiyi, 苗族蜡染技艺). There were also weaving techniques related to brocades: Nanjing Yunjin (南京云锦), Suzhou (苏州), Shu (蜀), Tujia's (土家族), Zhuang (壯族) nationality's, and Wunijing (乌泥泾) cottons. Li (黎族), Tibetan, Bai (白族), Uyghur, and Miao craftmanship was also listed (The Central People's Government of the PRC, 2006). The second batch of items, released in 2008, added more kinds 
of embroidery, among others ouxiu (瓯绣), bianxiu (泣绣), Han (汉绣), Qiang's (姜族), Sani (撒尼), Manchu, Mongol, Kyrghiz, as well as many spinning, weaving, printing, and dyeing techniques (The Central People's Government of the PRC, 2008).

Valery Garrett (1994, pp. 191-194) recognized silk, cotton, and hemp as being among the most important fibers used in the production of traditional clothing in China. Silk appears to occupy a special position; its introduction, according to legend, is associated with the wife of the Yellow Emperor. Leaving myths behind, it was discovered that silk has been used since the Neolithic period. Imperial silkworks were located in the cities of Suzhou, Hangzhou (杭州), and Nanjing (南京) during the Ming dynasty (明朝) (1368-1644). Silk was used as a tool in the hands of rulers who gifted it to China's tributary states and tribes. As Patricia Buckley Ebrey (2010, p. 70) describes, only in 25 BC did the Han dynasty (汉朝) (202 BC-220 AD) decide to present 20,000 rolls of silk as gifts. Moreover, in that year about 20,000 pounds of silk floss was designed to send, among others, to Xiongnu (匈奴).

This tactic was continued down through the dynasties, a practice inherited from a previous ruling power. Schuyler Cammann (2001, pp. 162163) has stated that cloth with the pattern used in the production of the emperor's robes was included as a giveaway. In addition, satin with the mang (蟒) pattern was also chosen. Cammann supposes that fabric rather than finished robes was sent in order to allow the recipients to prepare clothing suited to their own customs. Valery Garrett $(1998$, p. 5) observes that preserved examples of robes from the Ming dynasty can be found in Tibetan traditional clothing, a combination of Chinese fabric craftsmanship and Tibetan forms. This shows that silk was a highly valuable commodity to Chinese emperors.

The third batch of items, released in 2011, recognized the skills needed to create clothes in a Chinese style. Special distinction went to handmade Longfeng qipao (龙凤旗袍), Zhenxingxiang (振兴祥) Chinese style clothing, Hengsheng Fengbang (亨生奉帮), and Pei Luomeng Fengbang (培罗蒙奉帮) tailoring skills, all based in the province of Zhejiang (浙江) (The Central People's Government of the PRC, 2011). The Longfeng qipao brand has its roots in the late 1930's. Its origin may be found in the Zhu Shunxing (朱顺兴) Clothing Shop established by the tailor Zhu Linqing (朱林清). Later, because of cooperation with four other shops, it was developed into the Lonfeng qipao. 
Qipao (旗袍) designed by this brand present the Shanghai (上海) style with its characteristic fusion of East and West. Handmade tailored garments are created using the best quality materials, such as brocade, embroideries, and pankou (盘扣) (knot buttons) (Yang, 2014). During the 1930's Shanghai was a place where fashion flourished. Styles were changing fast and tradition merged with new ideas. Qipao, a one-piece gown developed from Manchu women's dress, gained more and more distinctive elements. One of them was sleeves in the Western style (Zhou \& Gao, 1998, pp. 228, 236). The Zhenxinxiang brand, with a tradition dating back to 1897 , is held by the Hangzhou Limin Chinese Garment Corporation (Hangzhou limin zhongshi fuzhuang gufen youxian gongsi, 杭州利民中式 服装股份有限公司). Hangzhou Limin preserves the skills needed to create not only the best quality qipao but also other Chinese-style clothes, both for men and women (Zhongguo fei wuzhi wenhua yichan wang, n.d.). Moreover, while issuing all batches of the Culture Ministry's list, the clothing of several groups was listed under the category of folk customs. This included women's dress from Luzhi (用直) and Hui'an (惠安), Changning Miao (昌宁苗族), Hui (回族), Yao (瑶族), Mongol, Chaoxian (朝鲜族), She (畣族)，Li， Lhoba (Luobazu，珞巴族)，Yugur (Yuguzu，裕固族)，Tu (土族)， Salar (Salazu，撒拉族)，Uyghur, Kazakh, Kyrghiz, Tajik, Daur (dawo'er zu, 达斡尔族), Ewenke (鄂温克族), Yi (彝族), Buyi (布依族), and Dong (侗族) (The Central People's Government of the PRC, 2006, 2008, 2011, 2014). This representation accounts for only a part of the fifty-six ethnonational groups recognized in total by China as living on its territory (Mullaney, 2011, p. 1).

\section{A CLASH OF THOUGHTS}

In popular discourse the word "fashion" is used in many combinations, such as: to be in fashion, seasonal fashion, old-fashioned, or fashion victim. On a theoretical level, however, the situation becomes more complicated. While looking for a definition of fashion, the building of a theory based on binary oppositions is strongly visible. Elizabeth Wilson $(2003$, p. 16) demarcated European style since the 14th century, and any other traditional garments. She insisted that fashion was born in Europe, alongside flourishing bourgeois life, the development of trade, and the more refined tastes of the aristocracy. Wilson's opinion seems to be a continuation of a tendency 
that is strongly rooted in fashion history, that is one in which Westerners perceive Asian fashion in a certain way.

For William Alexander in 1805, fashion did not influence Chinese dress. Clothes were simply changed to prepare for seasonal weather changes. Although his book was entitled The Costume of China, it gave the impression that it was written to describe the whole exotic Chinese culture, not just clothing. Nevertheless, it shows one of the conceptions concerning the existence of fashion in China that was current in the 19th century. Chinese dress was the antithesis to Western dress in Quentin Bell's conception, even if he also recognized that both clothing cultures shared the same leisure characteristics (Bell, 1948, p. 39). A blunter opinion was expressed by Lawrence Langner (1959, p. 285) who divided the world into three groups: The West, the Arab World, and Asia. Arabic countries were the buffer zone between the West, possessed by fashion fever, and Asia, seen as uncontaminated by fashion changes. A later uncompromising statement was made by Ann Hollander (1994, pp. 14-19) who openly used the term "non-fashion" about all non-Western clothing tendencies. She expresses and maintains this opinion in her publication, even if the narrative brings arguments that could be used to overthrow it, such as a recognition of the changeable characteristics of traditional garments. Hollander needs to clarify her point by expressing that the changes occur in different ways all of this in order to protect her original statement.

In some cases, the language of the discourse surrounding Asian clothing is significant, with the use of words such as static, stable, or artistic. Quentin Bell's Chinese clothing is "static" and "modest" (Bell, 1948, p. 40). Thorstein Veblen (1915, p. 175) used the words "static" and "more artistic" to describe the characteristics of Asian societies with their "relatively stable costumes". Such a viewpoint was necessary to prepare a proper contrast with Western culture, immersed in leisure and waste. As the author strongly identifies himself with the West, excessive ways of living seem to be praised. Fernand Braudel also drew a correlation between the level of a society's stability and fluctuations in fashion for the period between the 15th and 18th centuries. Unchangeable in his opinion, Chinese clothing and the Japanese kimono only served to prove his argument. Only by shaking up the social order and establishing a new political authority would there be a force strong enough to introduce change (Braudel, 1992, p. 312).

Voices in between these positions were represented by Edward Sapir, Carlo Belfanti, and Samuel Adshead. Sapir advocated spreading fashion in 
Asia, from the refined center towards its peripheries. However, fashion fever and rapid changes were reserved for modern Europe (Mandelbaum, 1963, p. 377). Belfanti and Adshead guarded the primacy of Europe, even if they acknowledged Asian achievements in the field. Adshead (2014, pp. 70-72) recognized the predominance of China's Tang dynasty (618-907) as a place where fashion was born, yet this phenomenon passed with the demise of this cosmopolitan dynasty. Fashion received a second chance after its real birth in Europe, where society did not let it down. Belfanti (2008, pp. 442-43) among others has analyzed the Chinese case and stated that there is no reason to call Europeans the inventors of fashion. However, in his opinion a "culture of fashion" that involves the whole society is a feature that is distinctively European. The global aspect of fashion was most important to him. This factor played a crucial role and made Europe the winner in the fashion game at a global level. In fact, his observations may give one the impression that a confrontation took place between "fashion" and "true fashion", where the "true fashion" was that emerging from Europe.

The third observed strategy is to take action against the primacy of European clothing tendencies. Linda Welters and Abby Lillethun (2018, p. 7) postulated a rewriting of fashion history because of noticeable Eurocentrism. They also objected to a static perception of all clothing that is not European. The necessity of a revision of the term "fashion" was also articulated by Jennifer Craik (1994, pp. ix-xi). The starting point was to break the dictate of European dominance and allow other options to be taken under consideration. The key point was not to depreciate European high fashion but to acknowledge the entirely rightful existence of other fashion systems. Each culture has its own fashion system and a mechanism which rules it. Although some aspects of fashion systems may aspire to be called unique, this is not the case with a fashion system when taken as a whole. Jack Goody (2007, p. 265) therefore disagreed as to the uniqueness of European conceptions of dress. Clothing was used in a similar way around the world; for example, rulers used it to force their ideas upon others and to control society. The power of fashion was seen in Europe, as well as in China. Dorothy Ko $(1997$, pp. 7,24$)$ has stated that Europe used Chinese dress as a tool towards achieving a better portrayal of itself. The truth behind the customs and characteristics of Chinese clothing and fashion tendencies was not that important. It was the discourse of the Other, clothed in a costume rather than in fashionable attire. 


\section{TRAVELLERS THROUGH IMAGINATION, INSPIRED VASSALS, AND COPYCATS}

Western fashion designers are practitioners. Their goal is to focus on the creation of new fashion, and to dictate it by themselves. While looking for a new source of inspiration, they may sometimes pay attention to the achievements of other cultures. Elements of magnificent Chinese dress styles are gladly incorporated into their own collections. This concept is not a new one. Since the 17th century, Chinese products, including textiles, were available in European markets. Desirable for their uniqueness, they were used to make gowns. This was a part of chinoiserie fever in Europe, which led to the collecting of Asian goods and the creation of rooms or gardens in an Asian style. China was able to protect its independence and did not let Europeans uncover all its secrets. As Richard Martin and Harold Koda have stated, the magical visions of the emperor's land are still vivid in today's fashion creations (Martin \& Koda, 1994, pp. 11-18). An interest in exotic China is seen in works presented by the most renowned designers and high fashion houses, such as Yves Saint Laurent, Dior, Gucci, Roberto Cavalli, Giorgio Armani, or Jean Paul Gaultier.

Yves Saint Laurent was known as the creator of postmodernist fashion. In 1962, his own couture house was established. His designs were the result of travel, history, and his personal contact with culture and art (English, 2013, pp. 99-100). In 1977, Yves Saint Laurent created his "Chinese collection" alongside a new, controversial fragrance named Opium. Nevertheless, traces of his Chinese inspirations were still visible even several years later. His projects continued to reflect the inspiration of the Qing dynasty (清朝) (1644- 1912). Although he borrowed characteristic elements of Chinese clothing, such as wide sleeves or floral motifs, he did not forget about the basis of his Western workshop (Musée Yves Saint Laurent Paris, n.d.a). His words cited in Elle in 1995 express his relationship with China:

Beijing, however, remains a dazzling memory. The China that I had so often interpreted in my designs was exactly as I had imagined it. All I need for my imagination to blend into a place or a landscape is a picture book. [...] I don't feel any need to go there. I have already dreamt about it so much. (Musée Yves Saint Laurent Paris, n.d.b) 
Thus, he incorporated his imaginations about China based on what he saw and heard without going there himself. This was the China of the Western imagination, mixed with European high fashion style. He managed to fully experience Chinese culture only once. This was during his stay in Beijing in 1985, when he attended his exhibition there (Musée Yves Saint Laurent Paris, n.d.a).

In 2004, Tom Ford created another Chinese-inspired collection for Yves Saint Laurent. He referenced the 1977 collection by using the pagoda shoulder concept. Ford introduced his own versions of Mao jackets and qipao (Mower, 2004). One of the gowns was in a vivid yellow color with a centrally placed five-clawed dragon, surrounded by smaller motifs (Fig. 1). This pattern was characteristic of the Qing dynasty's dragon robes

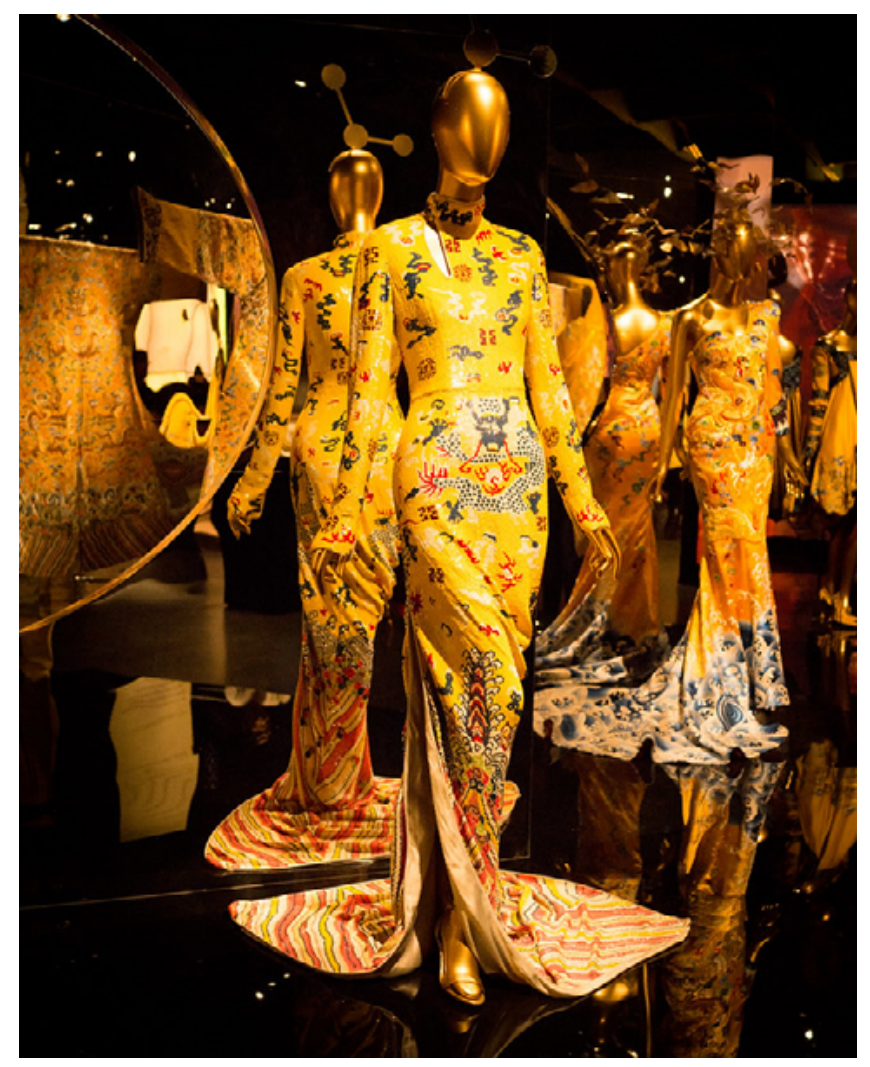

Fig. 1. Tom Ford for Yves Saint Laurent. A photograph taken during the exhibition China: Through the Looking Glass in 2015. (Victoria Pickering, https://www.flickr. com/photos/vpickering/34912601925/) 
(long pao, 龙袍). The version chosen by this designer was dedicated to the emperor himself; it was prohibited for others to wear this color. The fiveclawed dragon known as a long (龙) was reserved for the most prominent persons during the dynasty's flourishing period. The robe also contained other motifs with symbolic meanings, such as clouds and the Twelve Symbols of Imperial Authority. The lower part was finished with a striped pattern called li shui (立水) and mountains (Garrett, 2007, pp. 16-21). This scheme was all transported into Ford's design.

Chinese dragons and pagoda shoulders seem to be popular themes. This type of shoulders played a key role in a spring 2009 couture show prepared by Armani Privé (Mower, 2009). Ralf Lauren chose to include Chinese accents in his designs in 2011. For example, a red tuxedo with a shawl collar was decorated by a magnificent mang design, while a brown-black jacket was embroidered with a red long. Earrings and jade pendants completed the whole look (Phelps, 2011). In the pre-fall 2017 collection, an imperial dragon roamed on Gucci's pieces such as skirts, jackets, or shoes (Cardini, 2016). This mighty creature naturally blended with other patterns. As a result Gucci's characteristic style was still vivid. Previously, in the spring 2017 collection, a brown dragon dominated a green dress in a western style. On the same catwalk, a twin set of a jacket and a skirt made of rich pink Chinese jacquard was presented. Although the jacket had a mandarin collar and Chinese-style buttons, the whole garment looked more like one taken from 18th-century France during its period of chinoiserie fever (Vogue, n.d.d).

To Gucci, Chinese motifs appear to be something more than a oneseason inspiration. The spring 2016 collection contained a red midi skirt with a metallic embroidery of waves and floral patterns (Vogue, n.d.b). This embroidery pattern was based on actual skirts from the time of the Chinese Republic around the 1920's. Metallic threads, little pearls, which let one obtain a shiny effect on skirts and jackets, were among popular clothing decorations (Zhou \& Gao, 1998, pp. 221, 227). The fall 2016 collection included a long, black qipao embroidered with flowers, little birds, and a large phoenix. Moreover, sleeves were decorated with fluffy pink fur cuffs (Vogue, n.d.c). This gown was chosen by Melania Trump, as suitable for a state dinner held during US President Donald Trump's visit in China in November 2017. It was noted that the phoenix as a symbol of an empress was placed on the dress, although the whole piece was criticized as being too loud (Zhang, 2017). There is also one dress construction aspect 
which should be kept in mind when analyzing this project. Gucci's qipao was made in a western female style, where traditionally buttons or a zipper would be placed on the left-hand side. However, the Chinese followed the opposite pattern and fastened their clothing on the right-hand side. This was a distinction between the Chinese and "others", a sign of being a civilized person in the light of Confucian classic works. In The Analects of Confucius it is indicated that "wearing the hair loose and fastening one's clothes on the left are both barbarian practices" (Confucius, 2003, p. 161). In Chinese history, the wearing of clothing with left-hand fastening commonly designated one's foreign background. This was visible for example during the Tang dynasty (唐朝), when the clothing of the Hui Hu (回鹘) (predecessors of the Uyghur's) was in fashion among women (Zhou \& Gao, 1998, pp. 98-99). Another situation was fashion involved in political revolution with the left-hand-side opening of female dress being characteristic for those Chinese living under the jurisdiction of the Taiping Heavenly Kingdom (太平天国) (Zhou \& Gao, 1998, pp. 202-203).

Chinese objects, not just examples of clothing, may also be a source of inspiration. Roberto Cavalli created a distinct silk-satin evening gown in 2005. Although the gown had a very classical style, the woman who wore it looked like a precious Chinese vase, featuring a majestic dragon. Moreover, the train of the gown was printed with a small vase pattern (Nelson, 2015). Designs that include blue motifs upon a white background depict one of the most common styles of porcelain produced inter alia in Jingdezhen (景德镇). The dragon was one motif gladly used to decorate them. As early as the Ming dynasty, the city of Jingdezhen was able to produce porcelain destined for emperors, as well as export it abroad (Buckley Ebrey, 2010, pp. 217-219).

Design projects entitled "Fu Manchu" and "Shanghai Express" were among the propositions introduced by Jean Paul Gaultier during his fall 2001 couture show. Vogue seemed to react enthusiastically, predicting that even the Empress Dowager Cixi (慈禧太后) would be jealous after looking at Gaultier's stunning projects. According to the creator, "the idea was to bring together everything that you imagine when you think of China - theater, movement, color, history and richness" (Vogue, n.d.a). Leaving aside a discussion of aesthetics and personal preferences, there is a question over what this "imagination" really was. The name "Fu Manchu" appeared to be an especially controversial choice. Dr. Fu Manchu was the devilish Chinese villain in Sax Rohmer's early-20th-century novels. He was 
described as "the yellow peril incarnate in one man", the beneficiary of unpleasant features such as a satanic face or magnetic cat-like eyes (Rohmer, 1913, pp. 25-26). Within the term "yellow peril" were hidden all Western feelings of anxiety and fear towards Eastern nations. The threat of losing power to Asia was fueled by the portrayal of Asian characters in this way, doing battle with evil and devious forces. This image was also supported in subsequent Hollywood movies (Marchetti, 1994, pp. 2-3).

John Galliano's projects reflect his long interest in Asian themes. This interest can be traced in projects created for his own brand, as well as for Christian Dior. As he said, at first his works were an effect of the imagination, a world of fantasy, an experience of China under the Hollywood sign. Finally, Galliano found his way to discover the real China. The culture of minority groups was part of it, with Miao jewelry serving as an example (Guiducci, 2015). The apparel of the Miao ethnic minority is diverse, with each group having its own tradition. It appears that examples of jewelry used by Galliano are characteristic of the Qiandong (黔东) of the eastern Guizhou (贵州) and Guangxi (广西). Their outfits are decorated with heavy, silver ornamentation, among which elaborate headdresses can be found (Garrett, 1994, pp. 182-183). Ornate hairpins were part of Dior haute couture in 2003. Moreover, the models' catwalk was an arena for a Chinainspired show, with performers dressed like Shaolin (少林) monks (Mower, 2003). In 1999, the spring/summer collection for Dior was partially dominated by Galliano's vision of the Red Guards. He was interested in military uniforms and used some elements of this look (Guiducci, 2015). Designs in khaki tones, with orange berets or caps similar to these of the Red Guards had military vibes, while at the same time exposing a lot of the body. Some pieces contained a mandarin collar and were a variation of a military jacket. A piece of red or black cloth wrapped on the left arm of the models seems to have played the role of a crucial accessory (Fashion Channel, 2020). The red arm band was a sign of the Red Guards with one having been presented by a young student named Song Binbin (宋涁涁) to Chairman Mao Zedong (毛泽东), on August 18, 1966, at Tiananmen (天安门) Square. During this meeting Mao advised her to change name from Binbin (涁涁), since its meaning of gentle and refined was deemed not to be suitable for such a revolutionary time. Instead, the name Yaowu (要武), with its meaning of being militant, was considered desirable. The reason behind this was Mao's belief that "a revolution is not a dinner party [...]. A revolution is an insurrection, an act of violence..." (Sung, 1966, pp. 16-17). China 
Reconstructs magazine from that time, portrayed the Red Guards as devoted students who left school in order to fight for a better country during the Cultural Revolution. They swept the old culture and bad habits away, destroyed capitalist clothes and books, while at the same time introducing a new culture, suitable for the proletariat class (N.d., 1968, pp. 26-28). In addition, the Red Guards abused people possessing what they saw as a bad class background. They turned against their teachers, writers, cadres, or just used it as a chance to get back at others. They organized meetings where their victims were repeatedly tortured physically and mentally in front of a crowd. The effect of these actions was that many died before their time or committed suicide (Buckley Ebrey, 2010, p. 316). In this light, the choice of inspiration appears to be inappropriate, even if Galliano wanted to prepare his own revolution in the field of fashion. Examples of Galliano and Gaultier actions could be taken as an example of not deep enough understanding of history related to China and Chinese. Gaultier masked the true meaning of Fu Manchu name. Galliano somehow glorified Red Guards image, remembering only their loyalty to Mao Zedong, though forgetting the consequences of their actions.

\section{CONCLUSION}

The fashion world seems to be aware of the contribution of Chinese dress to Western fashion design. In some cases, Asian symbols are used to decorate garments aspiring to achieve an oriental look. In other situations, designers present their own vision of certain items of Chinese clothing. Among them, there is a group of individuals who have introduced the China of their dreams, the effect of their creative imagination. Blindly following one's imagination, however, without further checking on the background of one's ideas, can sometimes lead to controversies. All these tendencies were summarized in the exhibition China: Through the Looking Glass, prepared in 2015 by the Metropolitan Museum of Art, which created a space to show the impact of Chinese culture on Western fashion in one place (The Metropolitan Museum of Art, n.d.). Chinese-style dresses are not a fashion object that lasts for one season; on the contrary, they are to be seen as continuously existing. It appears that Chinese heritage is willingly incorporated by fashion designers in order to create original and characteristic collections. 
In academia, the position of Chinese dress as fashion is still not clear. Different voices are presented, with each concept having its own advocates and opponents. Denying the possibility of calling Chinese clothing fashion does not seem right in a situation where qipao are displayed at Western fashion shows. It appears that in order to change Western perspectives and research attitudes towards the application of the term of fashion itself, more studies of the history of Chinese dress should be made available in English. Preparing the National List of Intangible Cultural Heritage of China and promoting its acknowledged examples related to dress is a way to illustrate its high levels of artistry and skill. These enterprises represent the richness of Chinese culture which has led to the development of many textile styles and designs with regional characteristics. All in all, a change in perception may be fruitful in discovering other ways to create fashion.

\section{BIBLIOGRAPHY}

Adshead, S. A. M. (2014). Material Culture in Europe and China, 1400-1800. The Rise of Consumerism. The Palgrave Macmillan.

Alexander, W. (1805). The Costume of China: Illustrated in Forty-Eight Coloured Engravings. London: William Miller.

Belfanti, C. M. (2008). Was Fashion a European Invention. Journal of Global History. 3, 419443. https://doi.org/10.1017/S1740022808002787.

Bell, Q. (1948). On Human Finery. London: The Hogarth Press.

Braudel, F. (1992). The Structures of Everyday Life. The Limits of the Possible. London: William Collins Sons \& Co Ltd.

Buckley Ebrey, P. (2010). The Cambridge Illustrated History of China (2nd ed.). Cambridge: Cambridge University Press.

Cammann, S. (2001). China's Dragon Robes. Chicago: Art Media Resources.

Cardini, T. (December 13, 2016). Pre-Fall 2017 Gucci. Vogue. Retrieved August 13, 2020, from https://www.vogue.com/fashion-shows/pre-fall-2017/gucci\#coverage.

The Central People's Government of the PRC. (2006). Guowuyuan guanyu gongbu di yi pi guojia ji fei wuzhi wenhua yichan minglu de tongzhi [国务院爸于公布第一批国家级非物质文 化遗产名录的通知]. Retrieved April 8, 2020, from http://www.gov.cn/zwgk/2006-06/02/ content_297946.htm.

The Central People's Government of the PRC. (2008). Guowuyuan guanyu gongbu di er pi guojia ji fei wuzhi wenhua yichan minglu de tongzhi [国务院兊于公布第二批国家级非物质文 化遗产名录的通知]. Retrieved April 8, 2020, from http://www.gov.cn/zwgk/2008-06/14/ content_1016331.htm.

The Central People's Government of the PRC. (2011). Guowuyuan guanyu gongbu di san pi guojia ji fei wuzhi wenhua yichan minglu de tongzhi [国务院矢于公布第三批国家级非物 质文化遗产名录的通知]. Retrieved April 8, 2020, from http://www.gov.cn/zwgk/201106/09/content_1880635.htm. 
The Central People's Government of the PRC. (2014). Guowuyuan guanyu gongbu di si pi guojia ji fei wuzhi wenhua yichan daibiao xing xiangmu minglu de tongzhi [国务院爸于公布第 四批国家级非物质文化遗产代表性项目名录的通知]. Retrieved April 8, 2020, from http:// www.gov.cn/zhengce/content/2014-12/03/content_9286.htm.

Confucius (2003). Confucius Analects: With Selection from Traditional Commentaries (E. Slingerland, Trans.). Indianapolis: Hackett Publishing Company.

Craik, J. (1994). The Face of Fashion. Cultural Studies in Fashion. London/New York: Routledge.

English, B. (2013). A Cultural History of Fashion in the 20th and 21st Centuries. From Catwalk to Sidewalk (2nd ed.). London: Bloomsbury Academic.

Fashion Channel (April 11, 2020). CHRISTIAN DIOR Spring 1999 Paris - Fashion Channel. YouTube. Retrieved August 12, 2020, from https://www.youtube.com/watch?v=12c9sPx5AVU.

Garrett, V. M. (1994). Chinese Clothing: An Illustrated Guide. Hong Kong: Oxford University Press.

Garrett, V. M. (1998). Chinese Dragon Robes. Hong Kong: Oxford University Press.

Garrett, V. (2007). Chinese Dress: From the Qing Dynasty to the Present. Tokyo: Tuttle Publishing.

Goody, J. (2007). The Theft of History. Cambridge/New York: Cambridge University Press.

Guiducci, M. (April 21, 2015). John Galliano on Why He Loves Chinese Motifs. Vogue. Retrieved April 5, 2020, from https://www.vogue.com/article/met-china-catalog-costume-exhibitjohn-galliano-interview.

Hollander, A. L. (1994). Sex and Suits. The Evolution of Modern Dress. New York: Alfred A. Knopf.

Ko, D. (1997). Bondage in Time: Footbinding and Fashion Theory. Fashion Theory. The Journal of Dress, Body and Culture, 1(1), 3-27. https://doi.org/10.2752/136270497779754552.

Langner, L. (1959). The Importance of Wearing Clothes. London: Constable and Company Ltd.

Mandelbaum, D. G. (Ed.). (1963). Selected Writings of Edward Sapir in Language, Culture and Personality. Berkeley/Los Angeles: University of California Press.

Marchetti, G. (1994). Romance and the "Yellow Peril". Race, Sex and Discursive Strategies in Hollywood Fiction. Berkeley/Los Angeles/London: University of California Press.

Martin, R., \& Koda, H. (1994). Orientalism. Visions of the East in Western Dress. New York: The Metropolitan Museum of Art.

The Metropolitan Museum of Art (n.d.). China: Through the Looking Glass. Retrieved April 7, 2020, from https://www.metmuseum.org/press/exhibitions/2015/china-through-thelooking-glass.

Mower, S. (January 20, 2003). Spring 2003 Couture Christian Dior. Vogue. Retrieved April 6, 2020, from https://www.vogue.com/fashion-shows/spring-2003-couture/christian-dior.

Mower, S. (March 7, 2004). Fall 2004 Ready-to-Wear Saint Laurent. Vogue. Retrieved April 1, 2020, from https://www.vogue.com/fashion-shows/fall-2004-ready-to-wear/saint-laurent.

Mower, S. (January 26, 2009). Spring 2009 Couture Armani Privé. Vogue. Retrieved August 13, 2020, from https://www.vogue.com/fashion-shows/spring-2009-couture/armani-prive.

Mullaney, T. S. (2011). Coming to Terms with the Nation: Ethnic Classification in Modern China. Berkeley: University of California Press.

Musée Yves Saint Laurent Paris (n.d.a). L'Asie rêvée d'Yves Saint Laurent. Retrieved April 1, 2020, from https://s3-eu-west-1.amazonaws.com/musee-ysl-paris/press-releases/PK_YSLDreams-of-the-Orient_ENG.pdf.

Musée Yves Saint Laurent Paris (n.d.b). "Les Chinoises" Collection. Retrieved April 1, 2020, from https://museeys/paris.com/en/biography/collection-les-chinoises. 
N.d. (January 1968). The Revolutionary Rebel Spirit of the Red Guards. China Reconstructs, 17(1), 26-30.

Nelson, K. (May 5, 2015). Chinese Takeaway. W Magazine. Retrieved April 5, 2020, from https://www.wmagazine.com/story/metropolitan-museum-of-art-china/.

Phelps, N. (February 17, 2011). Fall 2011 Ready-To-Wear Ralph Lauren. Vogue. Retrieved August 13, 2020, from https://www.vogue.com/fashion-shows/fall-2011-ready-to-wear/ ralph-lauren\#coverage.

Rohmer, S. (1913). The Insidious Dr. Fu-Manchu. New York: McBride, Nast \& Company.

Sung, Y. (October 1966). I Put a Red Guard Arm Band on Chairman Mao! China Reconstructs, 15(10), 16-17.

Veblen, T. (1915). The Theory of the Leisure Class. An Economic Study of Institutions. New York: The MacMillan Company.

Vogue (n.d.a). Fall 2001 Couture Jean Paul Gaultier. Retrieved April 6, 2020, from https://www. vogue.com/fashion-shows/fall-2001-couture/jean-paul-gaultier.

Vogue (n.d.b). Spring 2016 Ready-to-wear Gucci. Retrieved August 14, 2020, from https:// www.vogue.com/fashion-shows/spring-2016-ready-to-wear/gucci/slideshow/collection\#2.

Vogue (n.d.c). Fall 2016 Ready-to-wear Gucci. Retrieved August 14, 2020, from https://www. vogue.com/fashion-shows/fall-2016-ready-to-wear/gucci/slideshow/collection\#30.

Vogue (n.d.d). Spring 2017 Ready-to-wear Gucci. Retrieved August 14, 2020, from https:// www.vogue.com/fashion-shows/spring-2017-ready-to-wear/gucci\#collection.

Welters, L., \& Lillethun, A. (2018). Fashion History. A Global View. London/New York: Bloomsbury Academic.

Wilson, E. (2003). Adorned in Dreams. Fashion and Modernity. London/New York: I. B. Tauris.

Yang, Z. (February 6, 2014). Tailoring tradition. Global Times. Retrieved April 11, 2020, from http://www.globaltimes.cn/content/840938.shtml.

Zhang, J. (November 10, 2017). Melania Trump takes floral fashion diplomacy to new lengths in China. South China Morning Post. Retrieved August 14, 2020, from https://www.scmp. com/news/china/diplomacy-defence/article/2119336/melania-trump-takes-floral-fashion-diplomacy-new.

Zhongguo fei wuzhi wenhua yichan wang (n.d.). Zhongshi fuzhuang zhizuo jiyi (zhenxing xiang zhongshi fuzhuang zhizuo jiyi) [中式服装制作技艺 (振兴祥中式服装制作技艺)]. Retrieved April 12, 2020, from http://www.ihchina.cn/project_details/14712.

Zhou, X., \& Gao. C. (1998). 5000 Years of Chinese Costumes. Hong Kong: The Commercial Press, Ltd. 